\title{
GCG Gene
}

National Cancer Institute

\section{Source}

National Cancer Institute. GCG Gene. NCI Thesaurus. Code C24422.

This gene is involved in glycogenolysis and gluconeogenesis regulation. 